\title{
Kvinnokroppen som text
}

\author{
ASTRID SCHLYTTER
}

Tillämpningen av $3 \S L V U$ sker på ett sätt för flickor och på ett annat för pojkar. I fråga om missbruksrekvisitet sker den könsmässiga differentieringen $i$ och med att annat än själva drogkonsumtionen och dess omfattning tillmäts betydelse för flickors del. Även rekvisitet "ett annat socialt nedbrytande beteende " har en könsmässig innebörd med diskriminering av flickor som följd.

Diskrepansen mellan rättens ideal om könsneutralitet och likhet inför lagen och den könsdifferentiering som sker i praxis är utgångspunkten för denna artikel. Bristen på överensstämmelse har sin grund $i$ att rättsliga bedömningar sker mot bakgrund av värderingar som ligger utanför rättssystemets ram. Syftet med artikeln är att beskriva och analysera den könsdifferentiering som sker i rättspraxis. Analysredskapen hämtar jag i första hand från kvinnoforskningen, och jag kritiserar i detta sammanhang begreppet genus så som det vanligen används i svensk kvinnoforskning. Själv använder jag begreppet kön och inte genus. Granskningen gäller ett rättsligt område, nämligen förutsättningarna för tvångsvård av unga människor enligt 3§ i lagen om vård av unga (1990:52), LVU. Jag bygger på den studie jag nyligen publicerat i boken Kön och juridik i socialt

Astrid Schlytter är fil.dr. i rättssociologi samt verksam som universitetslektor i rättsvetenskap vid Institutionen för socialt arbete, Stockholms universitet arbete. Tillämpningen av $3 \S L V U$ på länsrättsnivå(1999).

\section{Den lika rätten}

Den grundläggande idén om generell mänsklig likhet tillhör rättssystemets fundament. Rätten är lika och medborgarna är lika inför rätten. Detta innebär att rättsreglerna ska ha sin grund i likheten mellan människor och inte i olikheterna. I den rättsliga föreställningsvärlden är sålunda kvinnor och män lika. De står sida vid sida och deras relationer är baserade på förnuft och rationalitet. Eventuella avvikelser från detta, som diskriminering av kvinnor, är att betrakta som misstag som kan rättas till genom information och bättre planering (Smart 1995). När sådana korrigeringar eventuellt är relevanta kallas det jämställdhet. Jämställdhet är en könsmarkör; den säger att nu är kön relevant - en justering bör genomföras - vilket ska ske på ett könsneutralt, lika, sätt (Dahlberg 1995). 
Den lika rätten är ett ideal och ingen garanti för att den rättsliga regleringen faktiskt har sin grund i likheter mellan människor. Ett ställningstagande till vad som är det gemensamma förutsätter kunskaper om olikheterna. Även om olikheter förutsätts, avskiljs dessa (Svensson 1997). Olikheterna uppmärksammas inte, vilket bidrar till att vi inte upptäcker att det som framställs som neutralt och baserat på likhet faktiskt inte är det. Detta är en viktig ideologisk funktion hos rätten. Enligt den rättsliga ideologin ska det inte göras något åtskillnad på flickor och pojkar, trots detta behandlas flickor och pojkar olika. Dessa skillnader och den diskriminering som flickor utsätts för framkommer när teorin - hur det bör vara - jämförs med vad som faktiskt sker. Förutsättningarna för tvångsvård av unga människor enligt $3 \S$ LVU är att ungdomen genom sitt handlande bryter mot samhällets grundläggande normer och att det föreligger en påtaglig risk för att hans/hennes hälsa eller utveckling skadas. Normbrotten är i första hand missbruk av beroendeframkallande medel och brottslig verksamhet, men kan också vara av andra slag, "ett annat socialt nedbrytande beteende», som det heter i lagen. Det är socialnämnden som tar ställning till ungdomens behov och ansöker hos länsrätten om tvångsvård, 4 § LVU.

\section{Undersökningsmaterialet}

Mitt undersökningsmaterial är länsrättsdomar från 1994 beträffande ungdomar i åldersgrupperna 13-17 år. Domarna rör 293 ungdomar, drygt dubbelt så många pojkar, 209 (71 procent), som flickor, 84 (29 procent). Ett eller flera av paragrafens rekvisit kan ligga till grund för beslutet och för båda könen är »ett annat socialt nedbrytande beteende» mest förekommande. Men rekvisitet är av större betydelse för flickor, 62 (74 procent), än för pojkar, 117 (56 procent). Också missbruksrekvisitet spelar en större roll för flickorna än för pojkarna. 36 flickor (43 procent) och 56 pojkar (27 procent) uppfyller detta rekvisit. För brottsrekvisitet är pojkdominansen total. Endast 5 flickor ( 6 procent) och inte mindre än 107 pojkar (51 procent) uppfyller detta. Eftersom jag i första hand är intresserad av hur denna rättsliga reglering täcker flickors sociala problematik omfattar granskningen tillämpningen av missbruksrekvisitet och rekvisitet "ett annat socialt nedbrytande beteende». Vad beträffar det förstnämnda analyserar jag alla domar där ungdomen anses ha ett missbruk av beroendeframkallande medel. Jag indelar ungdomarna i två grupper efter missbrukets omfattning. För de som har ett lindrigare missbruk är alkohol den viktigaste drogen och för de övriga, som är dubbelt så många, är narkotika den främsta drogen. För det andra rekvisitets del gör jag flera begränsningar. Jag undersöker de fall där ungdomen fått vård enbart på grund av »ett annat socialt nedbrytande beteende» och har en social problematik som ligger utanför det som behandlas i förarbetena. Detta rör 21 ungdomar, 20 flickor och en pojke, vilket talar för att det är särskilda flickproblem som framkommer. Detta gör att jag enbart studerar flickorna i denna grupp.

\section{Tillvägagångssätt}

Domarna rekonstrueras och tolkas, vilket jag gör på delvis olika sätt för de två rekvisi- 
ten. Lagens missbruksbegrepp är allmänt och beroende av samhällsvärderingar (Schlytter 1999). Vad som är ett missbruk beror på drogens art och på drogens påverkan på ungdomens hälsa och utveckling. Alkohol är en accepterad drog och ett visst bruk är tillåtet, medan så är inte fallet för narkotika och droger som lösningsmedel. Allt bruk av dessa droger är i princip en fara för hälsa och utveckling (prop. 1989/90). I den juridiska metodologin skiljs rättsfrågan - vad som är missbruk enligt $3 \S L V U$ - från sakfrågan, vad som är missbruk i det konkreta fallet (Lindell 1987). Sakfrågan ska bygga på säkra fakta. Dessa ska så långt som möjligt dokumenteras (Diesen och Sutorius 1999, Schlytter 1999). Drogens art är av betydelse för hur missbruk i det enskilda fallet fastställs. För narkotika och dylika droger sker säkerställandet ofta genom urin- och blodprov medan det för alkohol krävs andra former för dokumentation. Hit hör intyg från läkare, rapporter från polisen och skolan, uppgifter från föräldrar eller ungdomen själv som ska belägga såväl konsumtionen som de möjliga sociala och hälsomässiga konsekvenserna. Underlaget för min analys är de fakta, sakförhållanden, som ligger till grund för bedömningen huruvida ungdomen har ett missbruk i lagens mening. Jag rekonstruerar den sociala kategoriseringen (Berge 1998) - vem som är att räkna som missbrukare - som framkommer i domstolsmaterialet. Dessutom jämför jag flickor med pojkar och har flickorna i fokus. Kön är ett relationsbegrepp som bland annat innebär att det definieras i förhållanden till det det inte är. Kvinnor och kvinnlighet definieras i förhållande till män och manlighet. Även om relationen till det andra könet kan vara tyst eller implicit betyder det inte att det outtalade könet inte är närvarande. Förutom att kvinnlighet respektive manlighet är beroende av det det är olikt är kvinnlighet respektive manlighet också fråga om en relation till det egna könet (Simonsen 1996). Kategorierna missbrukande flicka respektive missbrukande pojke som könsrelaterade begrepp bestäms sålunda i kraft av det mönster av underordning, dominans och diskriminering som råder mellan könen $\mathrm{i}$ samhället och i relation till normer och ideal för unga kvinnor respektive unga män.

I granskningen av rekvisitet nett annat socialt nedbrytande beteende» lyfter jag fram de olika problemsituationer som förekommer och relaterar det som kännetecknar dessa till riktlinjerna och konkretiseringarna i förarbetena. Eftersom mitt material enbart omfattar flickor blir detta också en jämförelse med könsmässig innebörd.

\section{Slutsats}

En övergripande slutsats är att rätten består av en dubbel uppsättning normer. Den ena utgår från pojkar och har större relevans för pojkar än för flickor och den andra utgår från flickor och har ringa relevans för pojkar. Rätten är sålunda inte neutral utan differentierar mellan flickor och pojkar. Samhällets företrädare "ser» och behandlar flickor och pojkar olika. Denna kunskap är inte ny, vilket bland annat framkommer av Gustav Jonssons studie gällande perioden 1947 till 1962, där han jämför flickorna och pojkarna på Barnbyn Skå. Den främsta anledningen till omhändertagande av flickorna var sexuellt leverne och av pojkarna brottslig verksamhet (1977). Sexualiteten spelade en vik- 
tig roll när det gällde att bestämma flickors asocialitet. Också senare studier visar att flickors sexualitet tillmäts en annan betydelse än pojkars. Bland annat används den för att bekräfta och förstärka olika former för asocialitet, som missbruk (Andersson 1995, 1996, Frisell 1996, Jeffner 1997, Sarnecki 1996, Öhlund 1997). Här ska dock tilläggas att sexuella problem i vetenskapliga sammanhang ofta förstås som det att vara sexuellt utnyttjad och inte det att sexuellt utnyttja andra. ${ }^{1}$ Detta innebär att sexualitet förknippas med flickors asocialitet och inte med pojkars. Sådana sätt att differentiera mellan könen är, enligt den engelska kriminologen Carol Smart, en följd av att kvinnokroppen tillmäts en annan roll än manskroppen. Smart anser att kvinnor i rättsliga sammanhang bedöms utifrån deras kropp och biologi medan män bedöms utifrån vad de gjort (1995).

\section{Missbruk - en dubbel uppsättning normer}

När det gäller alkohol är skillnaderna mellan vad som räknas som missbruk för flickor respektive pojkar tydliga. Det som räknas som missbruk för flickor är inte missbruk för pojkar. För flickor är en stor konsumtion under ett kortare skollov som jullovet eller en konsumtion som är accelererande och omfattar varje veckoslut inte tillåten. För pojkar är en alkoholkonsumtion utöver varje veckoslut inte tillåten, exempelvis när den blir intensiv under en period av några veck-

1 Se exempelvis studien: „Problemprofiler hos ungdomar inskrivna på särskilda ungdomshem i Stockholms län åren 1990-94", Sarnecki (1996). or eller omfattar även flera vardagar. När det gäller andra droger, främst narkotika, föreligger också olikheter. Pojkars missbruk har pågått längre än flickors. Bland annat har pojkar ett redan känt missbruk som det verkar som om myndigheterna inte har klarat av att åtgärda eller känt till men inte åtgärdat.

Könsmässiga olikheter förekommer också i hur missbruket fastställs. När det gäller alkohol är det för pojkars del den faktiska konsumtionen som dokumenteras, medan det för flickor är en lång rad företeelser och inte konsumtionen av alkoholen i sig som är avgörande. Händelser som att hon är skrikig, uppträder provokativt eller våldsamt, har samlag med flera pojkar eller blir misshandlad används både för att visa att flickan utsätter sin hälsa för en påtaglig risk att skadas och som underlag för att säkerställa själva alkoholkonsumtionen. Har flickan exempelvis samlag med flera pojkar på samma fest eller utsätts för våld, anses det manifestera att hon inte har kontroll över sig själv, vilket kopplas till berusningen. För flickor kompletterar eller ersätter sådana andra företeelser dokumentationen av alkoholkonsumtionen.

Detta gäller också för narkotika och liknande droger, även om tekniska säkerställanden spelar större roll för dessa droger än för alkohol. I nästan alla pojkdomar i denna grupp, 90 procent, föreligger tekniska säkerställanden medan detta är fallet för endast 50 procent av flickdomarna.

För att sammanfatta är resultaten dels att flickor tillåts ha en betydligt mindre drogkonsumtion än pojkar, dels att det föreligger könsmässiga olikheter i hur fastställandet i det individuella fallet sker. Rådande bevis- 
normer följs i all huvudsak i pojkdomarna medan avvikelserna från dessa är stora $i$ flickdomarna. Den könsmässiga differentieringen sker i och med att annat än själva drogkonsumtionen och dess omfattning tillmäts betydelse för flickors del. Pojkar bedöms utifrån drogkonsumtionen - alltså det handlande som är relevant enligt de rättsliga bevisnormerna - medan andra handlingar tillmäts betydelse för flickors del. Det finns ett mönster i vilka dessa andra handlingar är, nämligen att flickans möjliga eller faktiska sexuella beteende spelar en central roll.

\section{Hotfull legal sexualitet}

Trots att pojkar har en mer omfattande missbruksproblematik synliggörs inte deras sexualitet. Andra former av normöverträdelser dokumenteras emellertid, bland annat för att visa att det föreligger en påtaglig risk för att hälsa och utveckling skadas. Endast $i$ en dom redogörs det för normöverträdelser inom sexualitetens område. Pojken har begått sexuella övergrepp mot sin styvsyster, vilket är en brottslig handling och sålunda av ett helt annat slag än de sexuella beteenden som räknas som relevanta normöverträdelser för flickors del. Vad som fattas i domarna är beskrivningar av pojkars sexualitet och deras roll i en sexualitet som för flickor betraktas som icke önskvärd. Det kan ju inte bara vara i flickors missbruksmiljöer som det finns pojkar och det är helt osannolikt att det alltid är andra pojkar än de som får LVU-vård som flickor har den icke-önskvärda sexualiteten med. Det synsätt som förmedlas är att det är de unga kvinnorna som ska se till att de inte blir utnyttjade, som ska sätta gränser för pojkars/ mäns sexualitet. Detta bidrar till att osynliggöra pojkars roll och ansvar i det sexuella utnyttjande som flickor i missbruksmiljöer ofta utsätts för (Andersson 1996).

\section{Kvinnokroppen och alkohol}

De könsmässiga skillnaderna i missbruksdomarna visar att ungdomens biologi och kropp spelar roll för bedömningen. För flickor tillmäts, som nämnts, sexualiteten betydelse inte bara för att bestämma de sociala konsekvenserna av drogkonsumtionen utan också för att fastställa själva drogkonsumtionen. Att kvinnor och män bedöms olika på grund av kroppsliga olikheter är i vissa sammanhang allmänt accepterat. Exempel på detta är alkoholnormerna för gravida kvinnor. Kvinnor förutsätts vara helnyktra under graviditeten och ska då inte heller röka eller utsätta kroppen för andra faror. Normen om helnykterhet gäller också när kvinnor ammar. Då är kvinnokroppen mat (Solheim 1998). Dessa normer är kopplade till kvinnors biologi. Frågan är om det inte är denna biologism som ligger till grund för den särbehandling av flickor i 13-17 års åldern som framkommer i rättspraxis. Flickorna ses inte som självständiga individer som bedöms utifrån sina handlingar. Istället ses de som bärare av en kvinnokropp och bedömningen sker utifrån en uppsättning föreställningar knutna till denna kropp. Detta kan vara föreställningar som de ovan nämnda, om den goda modern, men de kan också ha ett annat innehåll; exempelvis om den tillgängliga och sexuella kvinnokroppen (Solheim 1998). Alltså är det inte likgiltigt för oss om den unga personen är en flicka eller pojke. 
Normen för flickors drogkonsumtion, åtminstone vad alkoholen beträffar, är att flickor inte får ha en konsumtion så att de tappar kontrollen över sin kropp. I detta avseende skiljer min analys sig från Christina Anderssons (1995), som hon själv formulerar på följande sätt: "normer för flickor föreskriver total avhållsamhet» (1996 s 191). Min slutsats är att det inte är total avhållsamhet som förespråkas; flickan får konsumera alkohol, men hon ska när som helst kunna låta bli, hon får på inget sätt tappa kontrollen över sin kropp.

\section{"Annat socialt nedbrytande beteende»}

De 20 flickor som får vård på grund av »ett annat socialt nedbrytande beteende», trots att deras problematik inte ligger i linje med vad som framgår av förarbetena, har olikartade problem. Hälften av dem anses ha en psykisk störning och vara självmordsbenägna. En annan grupp om fyra flickor får vård därför att de har en aktiv sexualitet. Ytterligare en grupp om fyra får vård därför att flickan är rädd för sin pappa, bland annat pga att hon blir misshandlad. Utöver detta är det två flickor som får denna vård därför att de har problem som följd av att ingen vuxen kan ta hand om dem. Fortsättningsvis går jag in på de två förstnämnda grupperna.

\section{Aktivitetskrav}

De flickor som anses ha en psykisk störning och vara självmordsbenägna använder bland annat kroppen som ett uttrycksmedel. Detta gör de genom att skada/rispa sig, genom våghalsigt beteende, genom att ta överdos av tabletter eller genom anorexi. Detta är självdestruktiva beteenden som ligger utanför bestämningen av begreppet "ett annat socialt nedbrytande beteende». Denna formulering valdes framför begreppet levnadssätt, bland annat för att markera att livsstil och sätt att leva ligger utanför området för tvångsomhändertaganden. Det krävs ett aktivt beteende från ungdomens sida (prop. 1989/90 s 28) vilket självdestruktivitet inte anses vara. Ändå är det flickor som enbart har en psykisk störning/självmordsbenägenhet som fått vård. Frågan är vad detta står för. Är dessa beslut i linje med rättspraxis i stort, alltså att rättspraxis inte följer lagförarbetena, eller är de undantag? Jag anser att det sistnämnda är fallet._Antalet ärenden av detta slag är få. Vidare föreligger exempel på avslag vid liknande vårdansökningar. ${ }^{2}$ Dessutom anser en domare i länsrätten på en förfrågan beträffande ett ärende med den aktuella problematiken att den inte är ett "annat socialt nedbrytande beteende" (Barvér 1997). De ansökningar som länsrätten bifallit är sålunda undantag och snarare att betrakta som "toppen på ett isberg». Mot denna bakgrund är rekvisitet »ett annat socialt nedbrytande beteende» framförallt så som det avgränsas i förarbetena men också så som det tillämpas inte könsneutralt. Det har ett innehåll som innebär att flickor_diskrimineras i och med att många flickor inte får den vård de behöver. Enligt min mening är flickors destruktivitet genom att inte äta, att skära/skada sig osv (Bjerrum-Nielsen \& Rudberg 1990, Andersson 1995, 1996) lika

2 Exempelvis mål nr 11227-96, Stockholms länsrätt. 
viktiga uttrycksmedel för flickor som aggressivitet och våld är för pojkar. Utan att erkänna dessa flickors kroppsligt förankrade uttryckssätt kan vi inte hjälpa dem.

\section{Kontrollerad sexualitet}

Två typsituationer kring sexualiteten framkommer i domarna i gruppen "ett annat socialt nedbrytande beteende». Även om antalet domar är få (4) förmedlar de värderingar och sätt att se på flickor som har sin grund $\mathrm{i}$ allmänna mönster där flickors klädsel och beteende förknippas med en icke-önskvärd sexualitet (Andersson 1996, Öhlund 1997). I den ena situationen har flickan en och samma pojkvän och det är deras relation som anses behöva brytas. I den andra har flickan ett aktivt sexualliv utan fasta relationer. Det gemensamma för flickorna som har en fast pojkvän är att denne bor på flyktingförläggning. I ett fall är han betydligt äldre än flickan. Det är inga andra flickor i mitt material som får vård därför att de har en pojkvän som de har ett sexuellt samliv med. Normen för dessa flickors sexualitet har med pojken att göra; det är inte tillåtet att ha en varaktig sexuell relation med en pojke som inte har uppehållstillstånd $\mathrm{i}$ Sverige. Flickornas beteenden regleras, de får bära ansvaret och tas ur sin miljö och placeras på behandlingshem.

Flickorna som inte har en fast relation med en pojke anses "leva ut sin sexualitet", de har "ett sexuellt utmanande sätt». Mot bakgrund av deras situation i övrigt verkar sexualiteten ingå i ett mer självdestruktivt mönster med att skada sig själv, självmordstankar osv. Att denna sexualitet lyfts fram och fördöms beror på att den utövas av flickor. Motsvarande sexuellt beteende hos pojkar ges inte denna roll.

\section{Kroppssymbolikens roll i juridiken}

Genomgången visar på följande motsägelsefullhet. I vissa rättsliga sammanhang har kroppen betydelse, i andra, som när kroppen är ett uttrycksmedel för flickor, tillmäts den endast undantagsvis betydelse. I båda fungerar kroppen som en text. I de sistnämnda är kroppen en text som vi borde avläsa, men som den aktuella rättsliga regleringen avgränsar mot. Frågan är om detta är ett ställningstagande för särlagstiftning och en avvikelse mot rådande ideal om likhet mellan könen? Enligt min mening är det inte det. Även om problematiken berör flickor särskilt och på så sätt är en avvikelse från likhetsidealet, är rekvisit av detta slag i principiella avseenden inte nya. Rekvisitet brottslig verksamhet är exempel på ett sådant. Det reglerar i huvudsak pojkars asocialitet.

Den norska socialantropologen Jorun Solheim hävdar att kvinnokroppen är en text (1998). Hon anser att vi tänker både rationellt och symboliskt, där den "..... symbolske tenkemåte... til sitt vesen /er/ en metaforisk logik hvor den konkrete analogi är den bärende princip" (s 16). Problemet med det symboliska tänkandet, enligt Solheim är att det tillhör det för-givet-tagna, det vi inte ser. „Det som är for tett innpå oss, eller som vi er totalt invävd i, unnslipper ganska enkelt vår forståelse. Det forblir det gitte, som vi ikke kan tenke oss annerledes (s 13)«. Såväl mans- som kvinnokroppen är en text, där symboliska mönster och kulturella me- 
ningssammanhang skapas, men de har olika innebörder (1998). Kvinnokroppen som en specifik symbolisk konstruktion existerar inte enligt den formella rätten. Följderna av detta på det aktuella rättsliga området är för det första att rätten inte har instrument för att synliggöra de krafter som påverkar rättstillämparens tanke- och föreställningsvärld. En icke-offentlig normbildning kommer sålunda att styra rättstillämpningen (Holter 1992, Schlytter 1999). För det andra kan vi i stort inte ge flickor som är fångna av sådana kroppssymboliska konstruktioner och som behöver hjälp för att komma ur självdestruktiva beteenden vård enligt $3 \S$ LVU. Denna vård kan i vissa fall vara livsavgörande.

Det är nödvändigt att synliggöra och erkänna kroppens symbolik som en realitet och därmed de krafter som styr vår tanke och föreställningsvärld, för att kunna "se» dessa föreställningar, granska dem och ersätta dem med rationell kunskap (Solheim aa). Om vi inte förstår kvinnokroppens särskilda symboliska roll kommer vi inte att förstå innebörden av det mönster av förtryck, kontroll och förnedring som unga kvinnor behöver anpassa sig till. En följd av detta är att vi inte ser hur nödvändigt det är med normer som sätter gränser för pojkars beteenden och som gör pojkar ansvariga för kränkningar av flickor. I dag är det flickorna allena som ställs till ansvar.

\section{Kropp och kön}

De kroppssymboliska föreställningarna upprätthålls och reproduceras i mötet med kroppen. Samtidigt är kroppens materialitet något annat än kroppens symboliska funk- tion (Solheim 1998). Kroppen är på samma gång materialitet och symbol och för att kunna förhålla oss till det senare är det viktigt att nyansera kroppsbegreppet. Det är nödvändigt att kunna skilja mellan kroppsliga funktioner som är relevanta för våra liv å ena sidan och kroppsligt förankrade normer där kroppen fungerar som en symbol å den andra.

Kroppens betydelse har under lång tid haft en central plats i den kvinnovetenskapliga teoriutvecklingen. Under 1970-talet kritiserades föreställningen om den naturliga kvinnliga underordningen och som ett led i detta tydliggjordes distinktionen mellan det sociala och det biologiska könet. Nya begrepp som genus och genusordning skapades i syfte att skilja kultur från biologi och denna distinktion kom också att få en dikotomisk innebörd (Fridlizius 1997). Enligt detta synsätt anses biologin vara utan betydelse för förståelsen av vad som är kvinnligt respektive manligt (Fridlizius 1997, Hirdman 1988, Moi 1977). Denna dikotomisering ligger till grund för den konstruktivistiskt inriktade teori som historikern Yvonne Hirdman har utvecklat. Enligt Hirdman är det två logiker som bär upp genus som en dynamisk struktur; att manligt och kvinnligt inte bör blandas och att män utgör normen för det normala och allmängiltiga (1988, 1990). Såväl denna teori som genusbegreppet har under senare år kritiserats och ny teoretisk förståelse har växt fram. En filosofisk kritik är att det inte går att skilja det biologiska från det sociala eftersom kroppen ingår i en kultur där uppfattningarna om vad som är biologiskt är socialt bestämda (Butler 1997). En annan och empiriskt grundad kritik är att biologiska fakta 
kan ha relevans för vårt handlande. Exempel på fakta av detta slag är att kvinnokroppen har sämre förmåga att bryta ned alkohol än vad manskroppen har (Leissner 1998). Detta är en information som alla kvinnor bör få. Att fakta av detta slag är relevanta är dock inte det samma som att dessa i sig är bestämmande för hur vi lever våra liv. Det stora problemet med genusbegreppet är enligt min mening att det innebär en avgränsning mot det biologiska och att det skiljer det biologiska från det sociala. En annan uppfattning i linje med den filosofiska och empiriska kritiken är att det biologiska och sociala är vävt in i varandra. Begrepp och teorier som konstruerar en motsättning mellan det biologiska och det sociala har sålunda stora begränsingar som analytiska kategorier. Vi behöver begrepp som inte förnekar kroppens materialitet och kanske är det nödvändigt med flera begrepp för kroppen, begrepp som bland annat inkluderar resonemang om sambanden mellan kropp och subjektivitet. I detta sammanhang anser jag att den norska litteraturvetaren Toril Mois tankar är särskilt intressanta (1997). Hon förkastar begreppet genus till fördel för begreppet kön därför att det senare inte innebär en gränsdragning mellan det biologiska och det sociala. Moi hävdar watt biologin både är extremt viktig för kvinnor och att den inte är ett öde» (1997 s 108). Kroppen uppställer villkor för kvinnors handlande men bestämmer det inte. Moi anser att kroppen både är ett objekt och en situation, vilket är helt olika aspekter av kroppen. Som objekt har kroppen vissa fysiska egenskaper. Kroppen som situation avser att kroppen är grundvalen för mina erfarenheter av mig själv och världen. Mina erfarenheter är något annat än kroppen men inte oberoende av kroppen. Alltså är mina val, min frihet, beroende av kroppen. Jag är situerad; kroppen är en situation som i sin tur är i andra situationer (1997). Kvinnokroppens förmåga att föda barn tillhör dessa fysiska egenskaper vilka inte innebär att kvinnor behöver bli gravida och föda barn. Kvinnokroppens symboliska funktion uttryckt i socialt kränkande normer är att betrakta som en situation som kroppen är i och som vi inte behöver vara ett offer för. Dagens läge, i synnerhet för unga kvinnor, gör att behovet av distans till de symboliska meningsstrukturerna är stort. Ett uttryck för dessa föreställningars makt är det rådande kvinnoidealet som säger att kvinnor ska vara smala - dagens modeller har anorektiska kroppar - och det är därför vanligt att kvinnor bantar. Kvinnlighet knyts därmed till mat och öppnar för en fixering vid kropp och mat. Denna normbildning relaterar sig kvinnor till och för en del tar den över och blir det sätt de själva definierar sig på. Flera av flickorna i mitt domstolsmaterial är i denna belägenhet. De behöver hjälp att få distans till sin kropp - att inte bli uppslukade av de symboliska bilderna som har kroppen i fokus (Solheim 1998). Sammanfattningsvis behöver vi begrepp knutna till kroppen, bland annat begrepp som gör det möjligt att se det förgivet-tagna, som ger möjlighet till distans och till att förstå vad kvinnor utsätts för som grupp och som individer, utan att vi för den skull behöver förneka kroppens fysiska egenskaper. 


\section{Summary \\ Woman's body as text}

This article is about the discrepancy between the legal commitment to formal equality and the goal of gender neutrality as a vision and how it is implemented in practice. I study how the county administrative court applies the Compulsory Care of Youth Act (LVU) in relation to anti-social behaviour for girls and boys between 13 and 18 years old. The analysis shows that the law in practice is not monolithic and unitary: it differentiates on the grounds of gender. For example, boys are permitted to use more alcohol and other drugs than girls. When the court determines what is the non-acceptable drug-consumption it is the consump- tion that is in focus for boys, but for girls their sex in itself is also relevant. Sexuality matters for girls but not for boys. In practice the law differentiates between the sexes and in doing so it takes girls as sex or body. Boys are problematic not because of their bodies but because of their actions. This means that the same practices have different significations because they are read through different discourses. The body is a site of enormous symbolic work and symbolic production that we have to take into consideration. We have to recognize this discourse and see how it influences us to resist the discrimination of girls.

\section{Litteratur}

Andersson, Christina (1995) Marias barn - om ungdomars väg in i missbruk av alkohol och andra droger, Sober Forlag

Andersson, Christina (1996) Om struliga flickor - beteende och bemötande» i Armelius, BengtÅke $\mathrm{m} \mathrm{fl}$ (red.) Vård av ungdomar med sociala problem-en forskningsöversikt, Stockholm:

Statens institutionsstyrelse och Liber Utbildning $\mathrm{AB}$

Barvér, Christina (1997) Psykiskt störda ungdomar-En kritisk granskning av LPT och LVU, C-uppsats, Institutionen för socialt arbete, Stockholms universitet

Berge, Anders (1998) "Säg mig vem jag är ...Om identitetsordning och makt» i Historisk tidskrift 4

Bjerrum-Nielsen, Harriet \& Rudberg, Monica (1990) Jenters vei til rusmidler - et sosialiseringsperspektiv, Oslo: Noras

Butler, Judith (1997) "Det performativa könet« $\mathrm{i}$ Res Publica, Symposions teoretiska och litterära tidskrift 1-2, s 13-35
Dahlberg, Anita (1995) Jämställdhetslagen som paradox och dekonstruktion i Nordborg, Gudrun (red) 13 kvinnnoperspektiv på rätten, Uppsala: Iustus Förlag

Diesen, Christian och Sutorius, Helena (1999) Sexuella övergrepp mot barn. Den rättsliga hanteringen, Socialstyrelsen

Foss-Fridlizius, Rita (1997) Vetenskap- Feminism - Politik, till en social förståelse av den feministiska forskningen som en differentierad och heterogen helhet, Institutionen för vetenskapsteori, Göteborgs universitet.

Frisell, Ann (1996) Kärlek utan sex går an....men inte sex utan kärlek. Om gymnasieflickors tankar kring kärlek och sexualitet. Tumba: Mångkulturellt centrum

Hirdman, Yvonne (1988) Genussystemet - reflexioner kring kvinnors sociala underordning" $\mathrm{i}$ Kvinnovetenskaplig tidskrift $\mathrm{nr} 3 \mathrm{~s}$ 49-63

Hirdman, Yvonne (1990) Genussystemet i Demokrati och makt i Sverige. Maktutredningens slutrapport, SOU 1990:44. 
Holter, Harriet (1992) "Kvinnor liv och arbete - en tillbakablick»i Acker, J m fl Kvinnors och mäns liv och arbete, Stockholm: SNS

Jeffner, Stina (1997) Liksom våldtäkt, typ-ombetydelsen av kön och heterosexualitet för ungdomars förståelse av våldtäkt, Uppsala

Jonsson, Gustav (1977) Flickor på glid-en studie i kvinnoförtryck, Stockholm: Tiden/Folksam

Leissner, Tom (1998) (red) Alkohol, Lund Studentlitteratur

Lindell Bengt (1987) Sakfrågor och rättsfrågor, Uppsala: Iustius Förlag

Moi, Toril (1997) Vad är en kvinna? Kön och genus i feministisk teori i Res Publica, Symposions teoretiska och litterära tidskrift 1-2 s 71 158

Regeringens proposition 1989/90:28 Vård i vissa fall av barn och ungdomar

Sarnecki, Jerzy (1996) »Problemprofiler hos ungdomar inskrivna på särskilda ungdomshem i Stockholms län åren 1990-1994«i Armelius, Bengt-Åke $\mathrm{m} \mathrm{fl}$ (red.) Vård av ungdomar med sociala problem-en forskningsöversikt, Stock- holm: Statens institutionsstyrelse och Liber Utbildning $A B$

Schlytter, Astrid (19999 Kön och juridik i socialt arbete, Tillämpningen av $3 \S L V U$ på länsrättsnivå, Lund: Studentlitteratur

Smart, Carol (1995) Law, Crime and Sexuality. Essays in Feminism, London: Sage Publications

Simonsen, Dorthe, Gert (1996) Könnets grenser, Center för kvinde- och könsforskning, Köbenhavns universitet

Solheim, Jorun (1998) Den åpne kroppen. Om kjönnssymbolikk i moderne kultur, Oslo, Pax Forlag A/S

Svensk författningssamling, SFS, (1990:52) Lag med särskilda bestämmelser om vård av unga

Svensson, Eva-Maria (1997) Genus och rätt-en problematisering av föreställningen om rätten, Uppsala: Iustius Förlag

Öhlund, Thomas (1997) Normaliseringspraktiker $i$ det moderna samhället, en diskursanalys av åtta sociala ungdomsprojekt, Umeå: Institutionen för socialt arbete, Umeå universitet.

\title{
Dags att förnya prenumerationen på Socialvetenskaplig tidskrift 2000
}

\author{
Prenumerationspriser per år, SE K \\ Sverige Norden Övrigaländer \\ Enskild 175:- 210:- 220:- \\ Institution 375:- $\quad 410:-\quad$ 420:-
}

FORSA tillhandahåller tidskriften åt medlemmarna. Enskilda nummer av tidskriften kostar 110:-, dubbelnummer 150:- .

Skicka prenumer ationsbeställningen till:

Prolog Medlemsservice, Sjödalsbacken 2, 14161 Huddinge, fax 08-774 13 77, tel. 08-779 55 19, e-post: prolog@swipnet. se, Pg 13435 97-9. Org.nr 556200-3862

Under 2000 kommer vi att presenter a många spännande artiklar och teman. 


\title{
Kvinnoidentitet och missbruksbehandling
}

\author{
KARIN TRULSSON
}

Sedan början av 1900-talet har det i Sverige funnits institutionsbehandling för missbrukande kvinnor. Denna har haft olika skepnader. Alkoholistanstalten för tvångsvård av kvinnor ersattes under slutet av 1960-talet av främst frivillig behandling tillsammans med män i terapeutiska samhällen. En återgång till ren kvinnobehandling både $i$ i frivilligvård och tvångsvård skedde under 1980-talet, efter att forskare funnit hur kvinnorna var osynliga och kom i skymundan av männen i vården. I artikeln berörs möjligheter att synliggöra och möta kvinnors behov av missbruksbehandling i ett terapeutiskt samhälle, som utvecklats utifrån ett genusperspektiv.

\begin{abstract}
Mycket har skrivits om missbrukarvårdens intentioner och innehåll. Det handlar ofta om allmänna beskrivningar av klienterna och vilka behandlingsmetoder de blir föremål för. Mer sällan urskiljs vårdens specifika betydelse för män, respektive kvinnor. På behandlingshemmen är männen i majoritet, eftersom andelen män och kvinnor inom vården motsvarar deras antal bland missbrukarna. Detta innebär att omkring var
\end{abstract}

Karin Trulsson, fil.lic. och doktorand vid Institutionen för socialt arbete i Lund samt verksam vid Kvinnoforum. fjärde alkohol- och narkotikamissbrukare är kvinna (Österling 1997, UNO-92). Kvinnornas minoritetsställning och osynlighet inom vården har berörts i 1980-talets forskning om missbrukarvård på behandlingshem för män och kvinnor. Bristerna när det gäller specifika behandlingsmetoder för att möta kvinnornas behov inom missbrukarvården belyses också (Björling 1989, Duckert 1989, Segreus 1990). Fanny Duckert talar om kvinnorna på behandlingshemmen som "ensamma svalor i en manligt dominerad flocku. En debatt beträffande missbrukarvården för kvinnor bidrog till att alternativ behandling 
börjat utvecklas under sista decenniet. Kvinnoinstitutionen återuppstod under nya förtecken från kvinnorörelse och kvinnoforskning (Trulsson 1993).

Erfarenheterna som redovisas i artikeln härstammar från ett terapeutiskt samhälle, Sofia behandlingshem i Malmö. Alkoholoch narkotikamissbrukande kvinnor har deltagit i behandlingen alltsedan starten 1990. I samband med utvecklingen av verksamheten var kunskaperna bristfälliga, eftersom det i utgångsläget saknades skandinaviska studier beträffande terapeutiska samhällen enbart för kvinnor. Därför blev det viktigt att följa uppbyggnadsprocessen och utvecklingsarbetet. Detta skedde genom att lyfta fram frågor om hur kvinnor upplever sina livsvillkor, missbruket och vad de ser som väsentligt i behandlingssammanhang utifrån ett genusperspektiv.

Artikeln berör några frågeställningar. Hur ser de missbrukande kvinnorna på behandling i kvinnokollektiv? Hur påverkar idealbilden i samhället den missbrukande kvinnans livsvillkor och behov i behandling? Hur påverkar mäns och kvinnors olika socialisation deras livsvillkor och behov $\mathrm{i}$ behandling. Hur påverkar arbetsdelningen mellan könen kvinnornas upplevelser och uttalade behov i behandlingen?

\section{Behandlingspraktiken vid Sofia}

Sofia är ett behandlingshem med plats för tio kvinnor beläget i centrala Malmö. Behandlingsarbetet utgörs av miljöterapi med psykodynamisk inriktning som utvecklats utifrån ett genusperspektiv. Den individuellt avpassade behandlingen varar i genom- snitt ett år. Kvinnorna erbjuds lika lång eftervård. Gravida missbrukare kan få missbruksbehandling och behandling tillsammans med barnen genom ett samarbete mellan behandlingshemmet och ett barnhem i Malmö.

Detta samarbete har visat på goda behandlingsresultat för gravida missbrukare och spädbarnsmammor, men också på svårigheter för kvinnor att delta i traditionell miljöterapeutisk missbruksbehandling tillsammans med män (Trulsson 1989). Dessa erfarenheter har styrt uppläggningen av behandlingen i kvinnokollektivet. Svårigheterna för kvinnorna att tala om traumatiska upplevelser enbart i grupp har emellertid bidragit till en komplettering av den traditionella miljöterapeutiska behandlingen. Vid sidan om gruppsamtal och vardagliga sysslor i kollektivet har således tillkommit ett nytt huvudinslag i behandlingen, individuella samtal med en till varje kvinna knuten kontaktperson. Tanken är att genom stödsamtal öka kvinnornas självförtroende. Samtalsbehandlingen syftar också till att underlätta för kvinnorna att sätta ord både på egna möjligheter och svåra upplevelser för att därigenom kunna vidareutvecklas och bli fria från sina missbruksproblem. Kvinnornas relationer till man, barn och närstående berörs $i$ behandlingsarbetet. Anledningen är de "barriärer" (Duckert 1989) för kvinnor att söka sig till och fullfölja behandling, som skapas av att traditionell missbruksbehandling främst betonar vikten av den egna utvecklingen och inte i samma utsträckning relationerna till närstående. I behandlingen ingår också kroppsvård, skapande sysselsättning , information (kring t.ex. sexualitet, kvinnokroppen, droger och föräldraskap) 
och eftervård. Att Sofia liksom tre andra svenska kvinnokollektiv med liknande inriktning ligger i städer, företrädesvis storstäder, underlättar naturlig kontakt med ursprungsmiljön och återgången till vardagslivet ute i samhället.

\section{Tidigare forskning}

Det finns begränsade kunskaper om missbruksbehandling för kvinnor i ett renodlat kvinnokollektiv och dennas betydelse för kvinnorna. Såvitt jag kunnat se finns bara ytterligare ett par sådana skandinaviska uppföljande studier, som rör det norska kvinnokollektivet, Arken (Sarri 1990, Christensen 1996). Detta kollektiv arbetar med gruppbehandling, vars ursprung var arbete enligt Hasselapedagogiken (Sarri a.a.), men som efter en omstrukturering fick en inriktning mot Minnesotabehandling och miljöterapi anpassad till kvinnornas specifika behov (Christensen a.a.). Gruppen kvinnor som sökt sig till Arken har vanligen en problematik med långvarigt narkotika- eller alkoholmissbruk och tung social belastning.

I sina tankar om den sex till nio månader långa grundbehandlingen betonade kvinnorna kvinnogemenskapen som väsentlig. Den innebar att "för första gången ha en väninna att lita påı och att i gruppsamtalen dela med sig den till andra i samma situation. Andra behandlingsinslag som kvinnorna betonade var att bearbeta konfliktfyllda relationer till familj och nätverk och att under eftervårdstiden delta i AA/NA-grupper. En tredjedel av kvinnorna var mammor. Färre mammor än kvinnor utan barn blev drogfria. Mammor som blivit drogfria har återupprättat kontakten med barnen, men deras tidigare fantasier om att få tillbaka barnen har ersatts av värderingar, att barnens bästa ska vara i fokus och kvinnornas egna behov ska komma i bakgrunden.

Slutsatser som dras är att behandlingserbjudandet behöver tillrättaläggas för att underlätta för kvinnor med barn. Traumatiska upplevelser har medfört psykiska problem, vilket lett till förslag att ha psykolog och psykiater knuten till behandlingen. Arkens kvinnobehandling fungerar enligt Christensen (a.a.) för många kvinnor som en "fristad", eftersom skamfyllda upplevelser som missbrukare har varit svåra att bearbeta i grupper tillsammans med män.

Bland de mycket få renodlade kvinnobehandlingar för missbrukare som publicerat egna forskningsresultat, är EWA-kliniken vid Karolinska Sjukhuset i Stockholm. Uppbyggnaden av behandlingsarbetet och forskningen har skett parallellt (se Dahlgren 1991, Dahlgren \& Willander 1992). EWA-kliniken vänder sig till alkoholmissbrukande kvinnor inom sjukvården med såväl dygnsvård som poliklinisk behandling. Behandlingstiden är individuellt avpassad ett till två år. Behandlingen har syftat till att tidigt komma i kontakt med missbrukande kvinnor och har också nått väletablerade kvinnor som har arbete och lever i familj, ofta med en missbrukande man. Ensamstående mammor med barn är överrepresenterade. Behandlingen utgår från en helhetssyn, eftersom missbruket bara utgör en del av en vidare problematik som också rör arbetsoch familjeliv. I behandlingen ingår täta stödsamtal med en kontaktperson, gruppaktiviteter, anhörigsamtal, vid behov medicinsk behandling och socialkurativa åtgärder. Dahlgren (a.a.) ser kvinnans relationer 
till familj och barn som centrala och moderskapet är en stark drivkraft i rehabiliteringen. Samarbete har utvecklats med barnpsykiatri och familjerådgivning. Enligt Dahlgren har enkönad behandling stort terapeutiskt värde och uppskattas av kvinnorna, eftersom de "får lugn och ro i återhämtningsskedet, träffar medsystrar och kan tala fritt om kvinnoproblem». Hon ser också inläggning som mer effektiv än enbart poliklinisk behandling för många kvinnor som initialt behöver bryta den onda cirkeln och varva ner. I jämförelse med en kontrollgrupp deltagare från gängse alkoholistvård vid kliniken har kvinnorna vid EWA-enheten visat signifikant bättre resultat. Det starkaste sambandet med god prognos var behandlingstidens längd.

Behandlingsarbete i rena kvinnogrupper har visat sig överlägsen behandling i grupp med både män och kvinnor. Det visar en studie vid behandlingshemmet Veksthuset, Oslo, en blandad institution med miljöterapeutisk behandling enligt Phoenix Housemodellen (Vaglum \& Ravndal 1991). Kvinnor som fullföljt respektive avbrutit behandlingen jämfördes. Majoriteten av fullföljarna deltog under slutskedet av behandlingen $i$ en ren kvinnogrupp. De lyckades etablera goda relationer till andra kvinnor inom eller utanför kollektivet och bryta destruktiva mönster de haft i förhållande till män innan behandlingen. Kvinnorna som avbröt behandlingen hade däremot deltagit i blandad grupp. Till skillnad från kvinnorna i den framgångsrika gruppen inledde samtliga relationer till män under slutskedet av behandlingen. Erfarenheterna ledde till att författarna drog slutsatsen att skilda behandlingsprogram i slutskedet eller under hela behandlingstiden borde diskuteras, eftersom den framgångsrika gruppen talade om större självkänsla och tro på framtiden, genom att dela erfarenheter med andra kvinnor och utbyta stöd. Kvinnornas förmåga att etablera ett nära förhållande till signifikanta andra i slutskedet av behandlingen sågs som den avgörande faktorn för ett positivt resultat. Därför förordade författarna fokusering på relationen till närstående och väninnor under hela behandlingstiden. Olika kvaliteter $\mathrm{i}$ institutionsbehandling för missbrukande kvinnor har berörts i andra studier. Kvinnornas erfarenheter av fyra olika behandlingsprogram, renodlad kvinnobehandling och blandad behandling berörs $t$ ex av Hilte (1998).

\section{Teoretiskt perspektiv}

Vid utveckling av missbrukarvård för kvinnor ser jag det som centralt att ha ett genusteoretiskt perspektiv. Jag har tagit fasta på Yvonne Hirdmans (1988) tankegångar om genussystemet som ett nätverk av processer, fenomen, föreställningar och föväntningar som bildar mönster och ordnar kön och är en grundläggande ordning och förutsättning för andra t.ex. politiska och sociala ordningar. Det har två "bärande bjälkar». Den ena är den hierarki, där mannen är norm och den andra »isärhållandets tabu». Hirdman talar om en generell kvinnlig underordning. Hon lägger mindre vikt vid klasstillhörigheten än könstillhörigheten, även om hon nämner att den kan problematiseras. Jag kan se att de missbrukande kvinnorna har en underordnad position. Däremot vill jag inte som Hirdman betona en generell kvinnlig underordning utan snarare 
ser jag klasskillnader och skillnader mellan olika kategorier av kvinnor som i lika grad avgörande för kvinnans villkor som könstillhörigheten (jfr Carlsson et al. 1983). „Isärhållandetsı logiker betonar skillnader och att manligt och kvinnligt inte ska blandas. Dessa innebär att varje samhälle och varje tid har ett kontrakt för samspelet mellan könen som styr synen på manligt och kvinnligt, sätter sin prägel på den enskilda människans liv och ger utslag i familjelivet. Detta behöver beaktas också vid utveckling av behandling. "Genuskontrakten" rör sig på tre nivåer: på kulturell nivå bl.a. idealtypen för man och kvinna, på institutionernas och arbetsdelningens nivå och på socialisationens eller individnivån.

Med den tankeramen som utgångspunkt finns det möjlighet att se de missbrukande kvinnorna utifrån idealbilden av att vara kvinna och hur missbrukande kvinnors liv kan ses som motbilden pga. diskrepansen mellan deras utsatta liv och idealbilden i samhället. Socialisationen av pojkar och flickor ser Hirdman som något som går i arv från från far till son och mor till dotter. Som gemensamt för bägge könen ser hon två "längtor i människobrösten" efter "frihet" och "symbios". För symbiosen står kvinnan och för friheten står mannen. Kvinnan lär sig tidigt utveckla nära relationer, medan mannen uppfostras till självständighet. Från detta utgångsläge utvecklas maktförhållandena mellan könen. Bägge söker ett balansförhållande. Mannen söker symbiosen, närheten hos kvinnan och den vill han med olika strategier kontrollera. Kvinnan söker friheten och självständigheten hos mannen. Enligt Hirdman innebär detta samtidigt kvinnans »förkroppsligade fängelse». Ge- nom sin kropp har kvinnan kunnat utveckla en "strategi för frihet och makt via mannens svaghet, men alltid via mannen«. Som jag ser det är sexualiteten och moderskapet väsentliga områden där kvinnan kan utöva makt. Samtidigt är just dessa områden, speciellt för missbrukande kvinnor många gånger också förknippade med vanmakt. Arbetsdelningen mellan könen och den institutionella nivån kan ses både utifrån den traditionella familjen, där kvinnan har ansvar för »hemmets sfär« och mannen för den "offentliga sfären" utanför hemmet (se Chodorow 1979). Den kan också ses utifrån senare års ombildade familj (se Krais 1993). I den familjen kan könsidentiteten ses som en produkt av arbetsdelning mellan könen, där tvåsamheten manligt och kvinnligt är förknippad med restriktioner. Både män och kvinnor har en potential som förtrycks. Det krävs aktiva ställningstaganden för att bryta med invanda mönster beträffande vad som ses som manligt respektive kvinnligt.

\section{Material och metod}

Studien, som utgör grunden till artikeln består av två delundersökningar. Den första Kvinnorummet (Trulsson 1993) följer uppbyggnadsprocessen av kvinnokollektivet samt kunskap och erfarenheter efter två år. Den andra Kvinnor på väg in från kylan (Trulsson, Länne, Nötesjö 1996) lyfter fram erfarenheterna efter fem år.

\section{Första delundersökningen}

Under verksamhetens första år från planering 1989 till och med 1992 dokumenterades uppbyggnadsprocessen. Ur olika synvinklar sökte jag kunskap om de missbrukande 
kvinnornas, de kvinnliga behandlarnas och omgivningens förväntningar och syn på behandlingen. Artikeln bygger på kvalitativa tematiserade intervjuer med samtliga tolv kvinnor som deltagit i behandlingen mer än tre och en halv månad. Kvinnorna intervjuades vid två tillfällen. Första intervjun berörde livet innan behandlingen och förväntningarna på behandlingen. Andra intervjun berörde kvinnornas syn på behandlingen $\mathrm{i}$ slutskedet av eller direkt efter avslutad behandling. Intervjuerna hade karaktären av livshistoriska intervjuer, även om livshistorien var sekundär och utgjorde bakgrunden till intervjun om behandlingen (se Bernler \& Bjerkman 1990. Tolkningen av materialet har utgått från en induktiv analysmodell (se t.ex. Eneroth 1986).

\section{Andra delundersökningen}

Andra delundersökningen omfattar bakgrundsdata insamlade av personalen enligt frågeformulär till de kvinnor som under perioden sedan starten 1990 till december 1994 ingått $i$ behandlingen mer än en vecka. Det gällde 44 kvinnor av den totala gruppen 53 kvinnor. Knappt hälften, 25 kvinnor av totala gruppen avbröt behandlingen under perioden. I den andra fördjupade delundersökningen fokuserades olika kvaliteter i behandlingen med utgångspunkt från erfarenheterna efter närmare fem år. Åtta kvinnor har intervjuats enskilt eller i grupp. I de individuella intervjuerna berörde var och en av kvinnorna ur olika synvinklar livet innan behandlingen, institutionsbehandlingen, livet efter behandlingen och synen på eftervården (se Bernler \& Bjerkman a.a.). I en tematiserad gruppintervju belyste kvinnorna sin syn på behandlingen.
I undersökningen följde jag upp centrala problemområden som identifierades $\mathrm{i}$ den första delundersökningen Metoden vid insamling och bearbetning av intervjumaterialet har utgått från den kvalitativa kvinnoforskningen (Davies \& Esseveld 1987, Smith 1987), eftersom jag anser den bäst kan bidra med förståelse av kvinnornas berättelser om sina liv och sina erfarenheter av behandling. Att jag i artikeln utgår från kvinnor som varit längre tid $\mathrm{i}$ behandlingen, då drop-outfrekvensen är låg, innebär en bild som synliggör olika kvaliteter i behandlingen, men kan tolkas som mer välvillig än en studie med alla kvinnor som deltagit i behandlingen, där "avhopparna» sannolikt har en mer negativ syn. Denna eventuella påverkan på informationen har balanserats upp i en senare studie beträffande kvinnor som avbrutit behandlingen (Nötesjö \& Tegborg 1999).

\section{Kvinnorna som deltagit i behandlingen vid Sofia}

Kvinnorna, som deltagit i behandlingen vid Sofia under tiden november 1990 t.o.m. december 1994, är en grupp där många har ett långvarigt missbruk och en belastad social situation. Gruppen kvinnor visar stor överensstämmelse både beträffande missbruksbild och social belastning med klienterna i BAK-SWEDATE undersökningen (Bergmark et al 1989). De har också likheter med gruppen patienter med missbruksproblem vid avd 1 F, Sankt Lars sjukhus, Lund (Fridell 1996). Andelen kvinnor med barn är större än i dessa bägge undersökningar och andelen alkoholmissbrukare större än i Lundaundersökningen.

Kvinnorna som deltagit i behandlingen är 
mellan tjugo och fyrtio år. De flesta är ogifta eller frånskilda. Två tredjedelar har barn, som i de flesta fall vistas i familjehem. Majoriteten saknade arbete året före behandlingen. Endast en kvinna uppbar lön av anställning. Tre fjärdedelar hade socialbidrag. Drygt hälften av kvinnorna hade bostad före behandlingen, medan resten var bostadslösa. Majoriteten av kvinnorna var narkotikamissbrukare och var fjärde var alkoholmissbrukare. I bägge grupperna var blandmissbruk vanligt. Mer än hälften hade missbrukat tio år eller mer. De flesta kvinnorna hade börjat missbruka i tonåren. Två tredjedelar hade vuxit upp i missbrukarfamiljer. En tredjedel av kvinnorna var dömda för kriminalitet. Missbruket är för några kvinnor förknippat med prostitution.

\section{Kvinnornas syn på behandlingen}

Gruppen med åtta av tolv kvinnor som var i slutskedet eller avslutat behandlingen under behandlingshemmets första år (grupp 1) tillfrågades om hur de såg på ett behandlingshem för kvinnor med enbart kvinnlig personal, vad de ansåg som mest verksamt i behandlingen och vad de var kritiska emot. Kvinnorna var genomgående positiva till ett behandlingshem för kvinnor, men det fanns delade meningar kring personalens sammansättning. I de individuella samtalen ville alla ha kvinnliga behandlare. Fem av kvinnorna ville ha enbart kvinnliga behandlare, eftersom det är mjukare med kvinnor, bra att slippa män ett tag. Tre kvinnor vill ha en eller ett par män i personalen. En kvinna uttrycker det:
- En man hade nog behövts. Finns det bara kvinnor kan man mer slappna av. Finns en man med så kanske man uppför sig lite bättre. Jag vill inte ha någon man $\mathrm{i}$ det direkta behandlingsjobbet.

Här kan man se kvinnornas kluvenhet till att dels ha fristaden med kvinnor, lugn, ro och närheten i samtalen, men hur några kvinnor också saknar männen och traditionellt manliga förhållningssätt $i$ »kvinnorummet».

Det som kvinnorna ansåg som speciellt verksamt $i$ behandlingen var att umgås med och lära känna andra kvinnor och de individuella samtalen med behandlarna. Fem kvinnor berör gemenskapen med de andra kvinnorna.

- Jag har fått mycket stöd och hjälp av de andra.

- Man lär sig umgås med andra tjejer. Det har ju funnits konflikter. Det har man inte lärt sig ta annars

Lika många kvinnor är positiva till de individuella samtalen och kontakten med behandlarna:

- Samtalen är bra och jag vet ju efter samtalen sitter jag och tänker mycket.

- Jag har fått mycket stöd av min kontaktperson. Med hennes hjälp har jag faktiskt kommit så långt att jag klarar av att öppna mej. Jag har varit rädd för det innan, för jag tycker att det har gjort så ont att lämna ut delar av mej själv. Det tycker jag har gått bättre. Sakta men säkert har det gått framåt.

Eftervården och den fortsatta kontakten efter behandlingen på behandlingshemmet nämner alla utom ett par kvinnor. Kvinnorna vill ha fortsatt samtalskontakt med sin kontaktperson eller någon annan av behandla- 
rna och möjlighet att komma och besöka "att känna att man har Sofia kvar även om man har flyttat därifrån".

Det kvinnorna främst var kritiska emot i behandlingen var undfallenheten hos personalen att det är "för mycket "daltande","för lite krav", och "för lite raka rör". Hälften av kvinnorna tar upp sådana synpunkter. Motsvarande frågor belystes också vid andra omgången intervjuer individuellt och i grupp med kvinnorna som deltog i behandlingen ett par år senare (grupp 2).

I alla intervjuerna betonade kvinnorna att de var positiva till behandling på ett behandlingshem för kvinnor (jfr Christensen 1996, Dahlgren 1992). En kvinnas berättelse uttrycker betydelsen av behandling i kvinnokollektiv som har likheter med många andra kvinnors berättelser:

Jag tycker det är viktigt att ha tjejer att prata med. Man har ju rätt dåligt självförtroende från början som tjej och detta måste byggas upp. Man blir bättre hörd på ett kvinnokollektiv. Detta gäller i alla sammanhang. Jag har en mycket negativ inställning till när det finns män med i gruppen. Jag upplever det som otroligt hårt. Det var det som jag tyckte var mest negativt på det andra behandlingshemmet. Det var dödshårt. Man blev inte hörd, utan det var männen som dominerade kraftigt. Tjejer fick inte säja ett pip. Hade man gjort något dåligt så fick man verkligen höra det. Jag reagerade med att bli livrädd och bölade. Till slut vågade jag inte säja något. Det blir mycket mjukare på en kvinnoinstitution. Kvinnor behöver lära sig att tycka om sig själv mera och lära sig umgås med andra tjejer. Att ha väninnor och att lära sig att kvinnor är lika mycket värda. Vi är så nedtryckta som vi levat innan. Jag tror det handlar mycket om det.
Här ges bakgrunden till behovet av ett speciell fristad som ger kvinnorna utrymme att växa och hitta sitt värde. Berättelsen blixtbelyser kvinnornas upplevelser av en extrem underordning i en behandlingsvärld, där männen tydligt dominerar och förtrycket från missbrukarvärlden lever kvar inne på behandlingshemmen (jfr Björling 1989, Duckert 1989). Snarare än att växa och utveckla sitt självförtroende i behandlingen riskerar många kvinnor få uppleva att inte bli hörda och att lära sig leva kvar i sin dåliga självkänsla.

Närheten till och gemenskapen med andra kvinnor utgör enligt kvinnorna en viktig utvecklingsmöjlighet. Samtidigt utgör närheten också den främsta »stötestenen «. Kritiken från den andra gruppen berör att det är tröttsamt och innebär irritation med det ständiga nötandet med andra kvinnor och de konfrontationer som ingår i behandlingens vardag. Påfrestande relationer till andra kvinnor och de maktförhållanden som kan utvecklas inom ramen för en kvinnlig hierarki har också visat sig vara en av de vanligaste orsakerna till att kvinnorna avbrutit sin behandling (Nötesjö \& Tegborg 1999). En kvinna berättar:

Jag menar att jag kan ju inte älska alla människor. Det blir surt om det blir så att det skär sig, för det blir jobbigt för alla parter. Blir vi fullt hus med tio tjejer, så kan man ju inte gå omkring och älska alla, det säjer ju sig självt?

\section{Hörnstenarna i kvinnobehandling}

Fyra hörnstenar i kvinnobehandling blir tydliga efter att ha lyssnat till kvinnornas berät- 
telser. Majoriteten av kvinnorna tar upp några saker som varit betydelsefulla för dem $i$ anslutning till behandlingen. För det första talar kvinnorna om tryggheten att inte bli övergiven när man visar upp sina problem, framför allt symptomtoleransen vid återfall i missbruk. För det andra berör de möjligheten att i individuella samtal tala om sina problem och få tillit till sin behandlare (jfr Dahlgren 1991). För det tredje tar de upp gemenskapen med de andra kvinnorna i kollektivet. För det fjärde berör de eftervården och långsiktigheten $\mathrm{i}$ behandlingen ( $\mathrm{jfr}$ Christensen 1996, Dahlgren a.a.).

Några uttalanden belyser detta:

- Jag tror det är hela atmosfären, alltihop tillsammans. Det är kombinationen med all den gemenskap, att man mår bättre och tilliten framför allt. Det blir en jättetrygghet som man inte känt innan.

-Det tog lång tid. Jag litade inte på någon förrän jag hade tagit två eller tre återfall och ni fortfarande stod kvar och höll vad ni lovade. Det var då jag började lyssna och höra. Annars var det ju bara en massa svammel, åh ja de snackar så gott.

- Ute litar jag inte på en djävul mer än mej själv. Det gör man här och vågar. Just det att jag vågar tala om hur jag verkligen känner. Det är ett stort förtroende man ger behandlaren vid de individuella samtalen om man så säger, och det är en jätteviktig relation för mej. Man det är lika mycket med tjejerna här. Det är mycket jag går och pratar med tjejerna om. Det har jag aldrig pratat med någon annan om.

- Jag är ett långtidsprojekt. Har man missbrukat så lång tid så måste man ge sig tid att sluta också.

Gruppsamtalen och andra aktiviteter berörs bara med enstaka uttalanden och förefaller ha underordnad betydelse.

\section{Idealen och motbilden}

Kvinnornas berättelser visar på de svårigheter de upplever, att som kvinna och missbrukare inte leva upp till idealbilden i samhället. Många kvinnor verkar istället se sig med omgivningens ögon som motbilden till den nyktra, kontrollerade kvinnan, som håller hemmet samman (jfr Eriksen 1991). Öppet eller underförstått handlar berättelserna genomgående om utanförskap. Kvinnorna känner sig utpekade, har svag självkänsla och skäms över missbruket. En av kvinnorna sätter ord på detta och kvinnors speciella utsatthet:

Tjejerna är mycket mer utsatta i missbruk. Ofta är de beroende av killar. De blir mer utnyttjade, både sexuellt och så att fixa pengar och ha någonstans att bo. Tjejerna bor runt hos olika killar. De är oftare bostadslösa än killarna. Sedan är det också det, att tjejerna har sämre kontakt med sin familj när de missbrukar. Killarna får ofta komma hem till föräldrar och sånt. Det är mer fult att ha en dotter som knarkar än en son som knarkar. En kille som missbrukar. Det kan vara tufft och accepterat, åh han har en vild period.

Samhällets renhetsideal »madonnnan« står i skarp relief mot den missbrukande kvinnan som "fyllekäringen" och "horan«. Av kvinnornas berättelser framgår hur flickor och kvinnor får betala ett dyrt pris känslomässigt och socialt för att falla ur ramen (jfr Andersson 1993). Dålig självkänsla, skam och skuld för sina misslyckanden kan vara en av anledningarna till att kvinnorna fann de individuella samtalen med behandlarna som speciellt betydelsefulla. Kvinnornas positiva inställning till individuella samtal för stöd, bearbetning och att stärka självkänslan i 
samband med missbruksbehandling liknar behandlingsmodellen som utvecklats inom sjukvården (jfr Dahlgren 1992). En inriktning mot individuella terapeutiska samtal efterlyses i samband med utvärderingen av det norska kvinnokollektivet (jfr Christensen 1996). Paralleller kan också dras med vägen ut ur prostitution (Hedin \& Månsson 1998), där stöd och bearbetning av traumatiska upplevelser i behandling ses som väsentliga för uppbrottet.

\section{Behov att utveckla kvinnoidentiteten}

Kvinnorna betonade några saker som bidrog till förståelse av vad som är verksamt i missbruksbehandling för kvinnor. Dels berörs de individuella samtalen med behandlarna som följer kvinnan i behandlingen och ut i eftervården, dels berörs gemenskapen med de andra kvinnorna i kollektivet. Detta blev en ledtråd som ledde fram till tanken att kvinnorna i kvinnokollektivet får möjlighet att ta igen det de tidigt förlorat genom brister i relation till den egna modern och till väninnor.

Att missbrukande kvinnor har gått miste om väsentliga inslag i sin socialisation belyses av Ravnndal och Vaglum (1991). De såg det nära samspelet med andra kvinnor och att kvinnorna får signifikanta andra som väsentliga inslag för framgång i kvinnobehandling. Genom en stärkt självkänsla kunde kvinnorna efter hand skaffa sig redskap för en mer självständig relation till män och att hantera sitt liv utan missbruk. De här intervjuade kvinnorna beskriver hur de genom den dagliga samvaron med andra kvinnor får möjlighet att utveckla sin identitet.
Den teoretiska förståelsen av en sådan utveckling av behandling för missbrukande kvinnor underlättas av Bjerrum-Nielsen och Rudbergs (1991) tankegångar kring flickans socialisation. Kvinnan utvecklar tidigt en relationellt förankrad identitet i nära samspel med mamman. I tonåren sker detta också i nära samspel med väninnor. Det finns skillnader mellan missbrukande flickor och flickor i allmänhet. När många kvinnor redan i tidiga tonår börjar använda alkohol och droger, riskerar de gå miste om viktiga inslag i sin utvecklingsprocess. Det är vanligt att föräldrarna ägnar dem lite uppmärksamhet pga. eget missbruk eller andra svårigheter. Missbrukande flickor har ofta få väninnor, eftersom deras annorlunda erfarenheter t.ex. av sexuella övergrepp och missbruk gör att de ses som udda och de har svårt att värna om sina psykiska och fysiska gränser. De torftiga relationerna till andra kvinnor kompenseras ofta genom närmast symbiotiska relationer till män. Det handlar ofta om missbrukande äldre pojkar och män, vars drogvanor många kvinnor tar över (jfr Andersson 1991).

Behandlingskollektiv för kvinnor förefaller att kunna kompensera dessa brister i nära relationer till andra kvinnor. I behandlingen kan många kvinnors förlorade tonårstid återskapas genom det nära samspelet med behandlarna, "morsorna", som kvinnorna ofta kallar dem, liksom väninnorna i kollektivet. Som tidigare nämnts kräver detta långsiktighet $\mathrm{i}$ behandlingen, som måste ske i kvinnans egen takt och inte kan forceras. Behandlingshemmet kan då fylla funktionen av »den goda familjen", där man sätter gränser med omtanke. I den gäller vid inträdet $\mathrm{i}$ vuxenvärlden, att var och en lär sig att efter 
hand finna sina egna gränser. Där är medlemmarna synliga och de kan göra sig fria utan att trygga relationer går förlorade. Symptomtoleransen behövs, eftersom man inte kastar ut en familjemedlem som brutit mot några regler. I stället sluter man upp, reder ut och tar om hand. Genom eftervården finns "familjen" kvar, när familjemedlemmarna flyttat hemifrån.

Studien beträffande kvinnor som avbrutit behandlingen vid Sofia belyser svårigheterna i kvinnobehandling och bidrar med en kompletterande bild. De nära relationerna och hierarkiska maktförhållanden i ett kvinnokollektiv kan också utgöra en belastning och ett hot för kvinnor med tidigare negativa erfarenheter i kontakten med andra kvinnor (se Nötesjö \& Tegborg 1999).

\section{Moderskapet som gemenskap och drivkraft}

Kvinnor med barn är överrepresenterade $i$ behandlingen (jfr. Dahlgren 1992). Två tredjedelar av kvinnorna på Sofia under de första åren och fortsättningsvis har varit mammor, medan traditionell missbruksbehandling har en jämn fördelning mellan ensamstående kvinnor och mammor (se Bergmark et al 1989). Att i behandlingen få stort utrymme åt relationen till barn och närstående är enligt de kvinnor som är mammor ett av de viktigast motiven till att de sökt sig till behandlingen. En kvinna uttrycker något som gäller för flera:

Nu skulle jag in där punkt slut. Jag tror att det blev så, eftersom de berättade för mig att det var viktigt att man behöll kontakten med sina barn under behandlingen, att det var positivt och att de skulle hjälpa till att barnen fick komma hit varannan helg. På det andra behandlingshemmet sa de till oss: Stäng ut barn och omvärld och då skulle man bara koncentrera sig på det där inne. Här var de plötsligt måna om att man skulle leva som vanligt.

Att moderskapet är en viktig drivkraft när det gäller att söka sig till och fullfölja sin behandling (jfr. Dahlgren 1992) visar sig både i mammornas beskrivning av behandlingen och i behandlingsresultaten. När samtliga tolv kvinnor (grupp 1) tillfrågades om målen för behandlingen uttryckte sju av åtta mammor på olika sätt ett bra liv med sina barn som det främsta målet. Behandlingsresultaten för kvinnor som väntade barn och var mödrar talar i samma riktning. Kvinnor som väntade eller hade barn fullföljde behandlingen i större utsträckning än andra kvinnor. De utgjorde mer än tre fjärdedelar av dem som fullföljde behandlingen.

Det är tydligt att de flesta missbrukande kvinnor värderar moderskapet högt. De försöker leva upp till en traditionell kvinnoroll med ansvar för hem och barn, vilket framgår av både min egen och annan forskning (Se t.ex. Andersson 1991, Trulsson 1998). Berit Andersson talar om att lika självklart som den missbrukande mannen prioriterar arbetet, lika självklart prioriterar den missbrukande kvinnan hem och barn. I samband med graviditeten avbryter eller minskar de flesta kvinnor sitt missbruk (Se Larsson 1980,Trulsson 1998). Förutom känslan för det väntade barnet visar det sig att kvinnorna söker sig till och tar hjälp främst av andra kvinnor, vilket skiljer sig från vad som tidigare framkommit i forskningen (se t ex Ravndahl \& Vaglum 1988, Tunving 1983). I samband med graviditet och moderskap förbereder sig kvinnorna och söker sin identitet 
som mor genom att liksom kvinnor i allmänhet vara öppna för den egna modern och andra kvinnor (Bibring et al 1961). Detta skiljer sig från den rädsla för och det avståndstagande till andra kvinnor, som jag tidigare sett är vanligt bland missbrukande kvinnor. Sannolikt är det en bidragande anledning till det ovanligt goda behandlingsresultaten för dem som är gravida och mödrar (Olofsson 1991, Trulsson et al 1996, Trulsson 1998). Att kvinnor tvingas avstå från eller minska kontakten med närstående i samband med vistelse på behandlingshem kan utgöra "barriärer", som hindrar dem att söka sig till behandling (jfr Duckert 1989). Behandling som går kvinnorna till mötes i en kvinnoroll som utgår från de nära relationerna förefaller öka möjligheterna att nå dem. När behandlingen tar hänsyn till och bejakar deras relationer till barn och närstående bidrar detta till stärkt självkänsla. Först som nästa steg $i$ behandlingen kommer att efter hand uppmuntra dem till att se egna behov. På sikt kan de finna en balans mellan egna och närståendes behov och att vidareutveckla sin självständighet. Erfarenheterna från behandling som verkar för att mammor av hänsyn till barnen skall avstå från tankarna att själva ta hand om dem pekar i motsatt riktning, genom att färre mammor än kvinnor utan barn fullföljer behandling (se Christensen 1996).

\section{Diskussion}

Behandlingshem för kvinnor med den här aktuella inriktningen grundar sig på tankegångar som överensstämmer med terapeutiska samhällen med psykodynamisk be- handling. Utgångspunkten är en vidareutveckling av Maxwell Jones behandlingsmodell, vilken utvärderats och beskrivits tidigare (Se t.ex. Hilte 1990). Hilte talar om den bärande behandlingsinriktningen i det kollektiv för män och kvinnor som han studerat. Förändring sker inifrån genom ny tolkning av självet och dess existens i världen. Vägen dit är att individen tar fullt ansvar och konstruerar ett ansvarsfullt jag. Självmedvetenhet och individuell reflektion spelar en betydande roll. Att bli sig själv uppnås i det terapeutiska samhället genom att terapeuten speglar klientens självuppfattning och idéer och att det är en jämbördighet mellan terapeut och klient.

Tankarna om självmedvetenhet och individuell reflektion som steg på vägen till konstruktionen av ett ansvarsfullt jag gäller även kvinnorna som deltar i den här beskrivna miljöterapeutiska missbruksbehandlingen. Vägen dit ställer emellertid krav på att se det specifika i kvinnors identitetsutveckling. Den här beskrivna behandlingsmodellen för kvinnor pekar på sådana möjligheter genom att överbrygga "barriärer" i traditionell missbruksbehandling som hindrar kvinnor att söka sig till och fullfölja behandling (jfr Duckert 1989). Samtidigt behövs medvetenhet om att frigörande behandling för kvinnor kan innebära konflikter. De "genuskontrakt" (jfr Hirdman 1988) som styr vad som förväntas av män och kvinnor utifrån idealbilden i samhället, socialisationen och arbetsdelningen mellan könen kan inte förbises $i$ en behandling som förväntas tillgodose kvinnnors behov för att uppnå ett liv utan missbruk. Kvinnornas berättelser har givit antydningar om problematiken, deras mål med och tankar kring behandlingen. 
Några ledtrådar framskymtar. Likheterna med andra kvinnor blir tydliga beträffande behovet av nära relationer till man, barn och närstående och ansvaret förknippat med den traditionella arbetsdelningen mellan könen. Med detta följer svårigheter att sätta sig själv och den egna utvecklingen i första rummet vilket är en av ledstjärnorna i traditionell missbruksbehandling. En annan svårighet är att leva upp till »myten om den goda modern" (Haavind 1974) som är gemensam för de flesta kvinnor. Den avgörande skillnaden mellan missbrukare och andra kvinnor är emellertid diskrepansen mellan den egna vardagsverkligheten med dess utsatthet och förnedring i förhållande de krav idealbilden i samhället ställer. Skuld, skam och dålig självkänsla blir resultatet av att inte lyckas leva upp till egna och andras förväntningar. Svårigheter under uppväxttiden gör att många kvinnor behöver i behandlingen ta igen vad de gått miste om under sin socialisation i fråga om nära gemenskap med andra kvinnor som missbruk från tidiga tonår bidragit till (jfr Ravndahl \& Vaglum 1991). Många missbrukande kvinnor har, ofta redan från barndomen, erfarenheter av traumatiska upplevelser. Detta visar sig i kvinnornas samstämmighet beträffande behovet av individuell samtalsbehandling. Detta ställer nya krav på behandlingen. Komplement behövs till gruppbehandling som utgör ett av huvudinslagen $i$ traditionella terapeutiska samhällen. Detta talar i samma riktning som erfarenheterna från kvinnobehandlingen inom sjukvården, där behandlingen främst består av individuella samtal i kombination med gruppaktiviteter. Där finns också en helhetssyn i behandlingen som omfattar familjen (se Dahlgren 1991).
Den inriktningen kan vara en av anledningarna till överrepresentation för kvinnor som har barn. Bättre behandlingsresultat för mammor än andra kvinnor i den här aktuella behandlingen visar på moderskapet som drivkraft i behandlingen och vikten av att i behandlingssammanhang inte avgränsa kvinnor från sina barn, utan snarare ge stöd och uppmuntra relationen mellan barn och föräldrar. Kvinnornas betonar gemenskapen med "väninnorna" i kollektivet, behov av trygga relationer och långsiktighet $\mathrm{i}$ behandlingen. Detta går att känna igen utifrån samstämmiga erfarenheter från de "kvinnorum" som efter hand växt fram i Skandinavien (Christensen a.a., Dahlgren a.a., Ravndahl \& Vaglum a.a.).

Men för vissa kvinnor kan »kvinnorummet« utgöra ett hot.. De här aktuella behandlingsresultaten, som visar en överrepresentation av mammor som fullföljer sin behandling, ger en antydning i den riktningen. Det ligger nära till hands att se stötestenarna för kvinnor som i missbrukarvärlden har erfarenheter av konkurrens med andra kvinnor om relationen till män. De har kanske under uppväxten upplevt besvikelser i förhållande till andra kvinnor och känner sig därför rädda för kvinnor. Kvinnor utan barn har inte hjälp av öppenheten inför andra kvinnor som finns inbyggd i processen att finna sin identitet som mamma (se Trulsson 1998a.). Snarare kan det vara traumatiska upplevelser, besvikelser och separationer som sätter sin prägel på deras nära relationer. Den drop-out studie som gjorts visar, att kvinnliga hierarkier och skilda livsvillkor utgjorde bakgrunden till att knappt hälften av kvinnorna avbröt sin behandling. Deras främsta kritik gällde vardagslivets täta relationer, ständiga nötande, 
irritationsmoment och konfrontationer (se Nötesjö \& Tegborg 1999).

Kvinnornas berättelser ger en inblick i vad som är specifikt i kvinnobehandling. Förtrycket kvinnor levt med i missbrukarlivet ställer krav på behandlingen att öppna möjligheter till stärkt självkänsla genom stöd och bearbetning av traumatiska upplevelser (jfr Hedin \& Månsson 1998). Att kvinnors missbruk i högre grad stigmatiseras och medför större utanförskap än mäns och innebär bl a att kvinnorna och människor i omgivningen behöver bli medvetna inte bara om kvinnornas inre värld, utan också om den yttre världen, där de skall leva efter behandlingstiden. Kvinnornas problem måste därför ses i relation till den sociala, ekonomiska, lagliga och politiska situationen (jfr. Björling 1989).

En reflektion om behandlingsutvärdering ligger nära till hands efter att ha lyssnat till kvinnornas berättelser. Ofta inriktas huvudintresset på hur klienterna klarat av en på förhand given behandlingsinriktning/teknologi. Mindre intresse ägnas åt vilken inriktning klienterna önskar sig i behandlingen. Ofta saknas dialogen hur behandlingen skall anpassas till den enskilda kvinnans eller mannens behov, eller med andra ord en teknologi som anpassats till råmaterialet (se Meyer \& Scott 1983). Utifrån det perspekti- vet väcks min nyfikenhet. Kanske är många av kvinnornas synpunkter inte speciella enbart för missbruksbehandling i kvinnokollektiv. Möjligen delar de drag också med vad män skulle vilja ha ut av behandling? En kunskapslucka blir tydlig. Enligt vad jag kunnat finna finns lite kunskap beträffande mäns och kvinnors likheter eller olikheter i upplevelsen av missbruksbehandling.

Vägar kan skönjas hur man kan gå missbrukande kvinnor till mötes i behandling. Detta har möjliggjorts genom det sista decenniets fokusering både teoretiskt och empiriskt på missbrukande kvinnor i behandlingssammanhang. Behandling i ren kvinnogrupp har givit goda behandlingsresultat (Christensen 1996, Dahlgren 1991, Dahlgren \& Willander 1992, Trulsson 1993, Trulsson et al 1996, Vaglum \& Ravndal 1991). Men vi befinner oss bara en kort bit på väg när det gäller att synliggöra och förstå några av skillnaderna mellan mäns och kvinnors behov i missbruksbehandling. Detta innebär möjligheter. Samtidigt finns anledning till vaksamhet mot rigida behandlingsmodeller, mer anpassade till den rådande samhällsordningen, än till vad lyhördhet inför vad den enskilda kvinnan eller mannen anser sig behöva utifrån vars och ens utgångsläge.

\section{Summary A woman's identity and the treatment of drug abuse}

A solution to the problems encountered by women in traditional treatment programmes for drug abuse has become treatment homes for women only and staffed by wo- men. Experience from Sofia treatment home in Malmö is the background for this article. Lack of knowledge concerning women's specific needs concerning treat- 
ment for drug abuse has led to research being done in close conjunction with the treatment being carried out.

In cooperation with the women who have participated in the treatment programme, a model for treatment has gradually been formed. The observations made during its' development has given us an idea of women's needs while being in treatment for drug abuse. This has led to a further progression of the psychodynamically based environment therapy. All the women who have been in treatment for longer periods of time are positive to the type of treatment the residential home provides. Slightly more than half the women who participated in the treatment the first five years have completed it.

Experience shows that a gender perspective is needed when developing treatment programmes. Consideration must be given to the ideals supported by society, men's and women's different socialization patterns and the division of labour between the sexes (cf. Hirdman 1988). There is a need to approach the problems related to the fact that women with a drug abuse problem do not live up to society's ideals and that an effect of this is feelings of guilt, shame and humilia-tion. The women especially valued the individual therapeutic counselling with a key worker who had contact with the woman throughout the treatment and during the after-care programme. They also valued their friendships with the other women at the treatment home, which illustrates that women can compensate for what they have missed during their period of socialization, during their early teens when they often start to take drugs. The division of labour between the sexes gives women the main responsibility for the home and the children. Lack of consideration for this fact creates "barriers" which hinder the women in the treatment of their drug abuse, whereas an acceptance of children and other close relationships during the treatment contributes to positive results.

Research concerning treatment programmes mainly focuses on how the client adapts to a preassumed type of treatment. Less interest is paid to the client's own wishes during treatment. There is often a lack of communication concerning how the treatment should be adapted to suit the individual woman's or man's needs. This question is raised as there is little knowledge concerning men's and women's similarities and differences in how they experience treatment programmes. It is possible that many of the women's views are not just applicable to the treatment of women. Perhaps they also have something in common with that which men would like to achieve from treatment.

\section{Litteratur}

Andersson, B. (1991) Att förstå drogmissbruk. Studentlitteratur, Lund.

Andersson, C. (1993) The Children of Maria. Acta Universitatis Upsaliensis: Göteborg Andersson, G. (1995) Barn i samhällsvård, Studentlitteratur, Lund
Bernler, G. och Bjerkman, A. (1990). Den sociala biografin., Göteborg: Daidalos

Bergmark, Å. \& Oscarsson, L. (1988) Drug Abuse and Treatment. Täby: Almqvist \& Wiksell International

Bergmark, A. m fl (1989) Klienter i institutionell 
narkomanvård. Uppsala: Uppsala Universitet, Pedagogiska Institutionen.

Bibring, G. L, Dwyer, T. F, Huntington, D. S. \& Valenstein A. F. (1961). "A study of the psychohological processes in pregnancy and the earliest mother-child relationship. Psychoanalytic Study of the Child, vol. 16, 162-186.

Bjerrum-Nielsen, H. \& Rudberg, M. (1991) »Jenters vej till rusmiddel, ett socialiseringsperspektiv“, Kön, rus och diciplin, Nordiska nämnden för alkohol och drogforskning, NAD publikation nr. 20.

Björling, B. (1989). »Making women visible« Women alcohol and drugs in the Nordic Countries, Nordiska nämnden för alkohol och drogforskning, NAD-publikation nr. 16.

Carlsson, C. Esseveld J., Goodman, S., Widerberg, K. (1983) „Om patriarkat en kritisk granskning", Kvinnovetenskaplig tidskrift. nr 1, 55-69.

Chodorow, N. (1979) „Mothering, male dominance and Capitalism", Capitalist patriarchy and the case for socialist feminism, N.Y. Monthly Review Press, 83-106.

Christensen, A. (1996) "Jenter som kommer og jenter som går «. Statens institut for alkohol-og narkotikaforskning SIFA rapport nr.6/96.

Dahlgren, L. \& Willander, A. (1991) "Vilka kvinnor söker hjälp för alkoholproblem, och vilka går det bra för?", Läkartidningen, vol. 88, 632635.

Dahlgren, L. (1992). „Behandling av kvinnliga alkoholmissbrukare", Socialmedicinsk Tidskrift, nr. 8, 1992, 390-394.

Davies, K. \& Esseveld, J. (1989) Kvalitativ kvinnoforskning. Stockholm: Arbetslivscentrum.

Duckert, F. (1989). »The treatment of female problem drinkers". Women alcohol and drugs in the Nordic Countries, Nordiska nämnden för alkohol och drogforskning, NAD-publikation, nr. 16.

Eneroth, B. (1986) Hur man mäter vackert? Grundbok $i$ kvalitativ metod. Stockholm: Akademilitteratur.

Eriksen, S. (1991) „Alkohol som könssymbol«. Kön, rus och diciplin, NAD-publikation nr. 20.
Fridell, M(1996) Institutionella behandlingsformer vid missbruk. Organisation - ideologi och resultat, Stockholm: Natur och Kultur.

Haavind,H. (1974) Myten om den goda modern. Aldus.

Hedin, U-C \& Månsson S-A. (1988).Vägen ut! Om kvinnors uppbrott ur prostitution, Stockholm: Carlssons Bokförlag.

Hilte, M. (1990) Droger och diciplin. En fallstudie av narkomanvård $i$ Malmö. Lund: Arkiv.

Hilte, M. (1998) Behandlare och kvinnliga klienter: Om vägen ut ur missbruket. Socionomen Tema Institutionsvård för vuxna missbrukare. Nr. 4, 69- 79.

Hirdman, Y. (1988) „Genussystemet - Reflektioner kring kvinnors sociala underordning". Kvinnovetenskaplig tidskrift, $\mathrm{nr}$ 3, 49-63.

Järvinen, M. (1983), »Kvinnan i alkoholforskningen", Kvinnoforskning kring alkohol och droger. NAD-Publikation nr. 8.

Krais, B. (1993) "Gender and Symbolic Violence» Ur Calhoun, C, m.fl. (eds), Bourdieu Critical Perspectives, London: Polity Press.

Larsson, G. (1980). The amphetamine addicted mother and har child, Acta paediatrica Scandinavica Supplement 278, Almqvist \& Wixell.

Meyer, J. \& Scott, R. (1983) Organizations and environments: Ritual and Rationality. Beverly Hills: SAGE .

Nötesjö, G. \& Tegborg, E..(1999) Tur och retur Kvinnorummet. Qlara Management AB: Stockholm.

Olofsson, M. (1991). Gravide misbrugere og deres born I: Kön, Rus och Diciplin - en nordisk antologi, NAD-publikation nr. 20.

Ravndal, E. \& Vaglum, P. (1988). Kjennetegn och behandlingsforlop hos ungdom som söker sig till Veksthuset, Institutt for medicinske adferdsfag, Universitetet i Oslo.

Ravndal, E. \& Vaglum, P. (1991) Behandling av kvinnelige stoffmissbrukere i ett hierarkisk terapeutisk samfunn: Betydningen av relasjoner till foreldre, partnere og veninner, Institutt for medicinske adferdsfag. Universitetet i Oslo 1991.

Sárfi, E. (1990). »Jenter i motvind«. Diakonhjem- 
mets Hogskolesenter, Forskningsrapport Nr. 34

Segreus, V. (1990) Institutionsvård för narkoma-

ner. Forskning om missbrukare och vården, särskilt tvångsvården,DSF.

Smith; D. (1987) The Everyday World as Problematic. A feminist Sociology. Boston: Northeastern University Press.

Trulsson, K. (1993). Kvinnorummet-Vision, verklighet, vardag. Rapport från ett behandlingshem för kvinnor. Kvinnoforum Utbildning AB, Ljungbergs tryckeri, Klippan.

Trulsson, K., Länne, L. \& Nötesjö, G. (1996) Kvinnor på väg in från kylan, Stockholm: Qlara Management AB.
Trulsson, K. (1998) "Det är i alla fall mitt barn"En studie om att vara missbrukare och mamma. Licentiatavhandling, Oskarshamn: Carlssons Bokförlag.

Tunving, K. (1983) „Den kvinnliga narkotikmissbrukaren i vårdsystemet. Kvinnoforskning kring alkohol.och droger., NAD-Publikation nr.8.

Uno-92. Det tunga narkotikamissbruket i Sverige 1992. CAN:s Rapport, serie 1993.

Österling, A. (1997). Alcohol problems in women, Malmö: Department of Clinical Alcohol Research Lund University. 